\title{
The WHO European monitoring surveys on national suicide preventive programmes and strategies
}

\author{
By Ellenor M ittendorfer Rutz and Danuta Wasserman
}

\section{The results of the two WHO European monitoring surveys on national suicide preventive programmes and strategies carried out in 52 WHO member states in October 2001 - February} 2002 and October 2003 - February 2004 are summarised. Countries are divided into two groups with respect to the existence of national suicide preventive initiatives. Suicide preventive activities within the mental health care services as well as public health prevention initiatives are presented.

\section{Introduction}

To assess the level of suicide prevention activities in countries of the W $\mathrm{HO}$ European Region, questionnaires were sent to contact persons in 48 of the 52 $M$ ember States (including Former Soviet and Central A sian Republics) in O ctober/ $\mathrm{N}$ ovember 2001; reminders were sent in February 2002. The follow-up survey took place from 0 ctober 2003 till February 2004. The contact persons were members of the W H O European M ulticentre Study, W HO national counterparts for mental health, or national representatives of the International A ssociation for Suicide Prevention. No contact persons were identified for Luxembourg, C yprus,

Tajikistan and U zbekistan.

A nswers were received from 39 of the 48 countries contacted. Results from both surveys are summarised. The countries were divided into two groups with respect to the existence of national suicide prevention initiatives, to reflect the level of comprehensiveness and co-ordination of preventive activities in the countries

(Table 1). Those with such initiatives have countrywide integrated activities carried out by government bodies. Countries without national initiatives carry out isolated activities in different parts of the country.

Of the 17 countries with national suicide prevention initiatives 14 have official documents issued by governments or administrative bodies such as ministries (Table 1). Seven of the national suicide prevention initiatives are approved by parliament. In Sweden, only parts of the programme (suicide prevention in young people) are approved by parliament.

$\mathrm{N}$ ational programmes with a variety of strategies have been established in A ustria, Bulgaria, C zech Republic, Denmark, Finland, France, G ermany, Icel and, Lithuania, $\mathrm{N}$ orway, Sweden and the $\mathrm{U}$ nited Kingdom (Table 1). Programmes are here understood as concise action plans, combining various specific national strategies in order to achieve predefined goals and objectives, whereas national strategies are defined as different preventive approaches established nationally in different settings. Some of the other countries with national suicide preventive strategies, like Estonia and Slovenia, report having started to draft national programmes. In 3 out of 22 countries, suicide prevention activities on county or community level are official documents (Table 1 ) and in Israel, Switzerland and Poland plans for national action have al ready been laid.

\section{Countries with national suicide prevention initiatives}

\section{a) A gencies implementing national suicide prevention initiatives}

$M$ inistries and national/regional public health institutes and agencies on the one hand, and nongovernmental organizations such as help-lines and psychiatric associations on the other, are involved in implementing the national suicide prevention initiatives in most of the countries. Finland and N orway have a pronounced multisectoral approach that also involves universities, hospitals, the church, the military, the police and the school system. N ational suicide prevention activities aim to lower the rates of completed and attempted suicide, and focus on research, surveillance, education, treatment and aftercare.

\section{b) M ental health care}

A variety of strategies to improve health care services are included in all national suicide prevention initiatives (Table 2). These range from projects to increase the consciousness of health care providers about early detection of suicide risk and adequate treatment, to improved access to mental health services, to improvements in crisis intervention and telephone crisis hotlines.

A II countries with national suicide prevention initiatives have an educational project either on improving the diagn osis of psychiatric illness or on the adequate treatment, follow-up and rehabilitation of psychiatric patients, those who attempt suicide and people in psychological distress (Table 2). Five countries report that they focus on only one educational theme. The main target groups for these educational projects are, with few exceptions, general practitioners and psychiatric personnel, while social workers seem to be involved in these projects in only about half of the countries. The inclusion of relatives, politicians and health care administrators as groups of special interest in these educational projects is seldom a general choice.

\section{c) Public health perspective}

W hile Public health suicide prevention activities like responsible media policy are increasingly introduced, regulations controlling access to means of suicide, are carried out in less than one third of the countries (Table 2).

In all countries, some sort of public education is performed in order to increase knowledge and awareness regarding suicide prevention and mental illness (Table 2). A II countries with national suicide prevention activities have public education focusing on the prevention, early recognition and treatment of mental illness. A II except four countries include information on the role of chronic psycho-social stress. M ost of these public education projects include some sort of information on the role of environmental protective factors.

Schools are the preferred arenas for public health interventions on suicide prevention, while only a few countries carry out educational projects in workplaces, housing areas and within the military. 0 nly three countries target politicians with educational activities, and only seven target administrators. Further reported settings for educational projects are prisons (Slovenia), the police (Estonia, Lithuania, N orway), the church (Iceland, Finland) and the media. Finland has developed a special model that includes close collaboration with the church and the police. 
Table 1. Level of national action on suicide prevention

\begin{tabular}{|c|c|c|}
\hline $\begin{array}{l}\text { C ountries } \\
\text { with national } \\
\text { prevention } \\
\text { initiatives }\end{array}$ & $\begin{array}{l}0 \text { fficial } \\
\text { documents }\end{array}$ & $\begin{array}{l}\text { A pproved } \\
\text { by } \\
\text { parliament }\end{array}$ \\
\hline A ustria ${ }^{a}$ & + & - \\
\hline Bulgaria $^{a}$ & + & - \\
\hline $\begin{array}{l}\text { C zech } \\
\text { Republic }^{a}\end{array}$ & + & - \\
\hline Denmark $^{a}$ & + & + \\
\hline Estonia $^{b}$ & + & - \\
\hline Finland $^{a}$ & + & - \\
\hline France $^{a}$ & + & - \\
\hline G eorgia & + & + \\
\hline G ermany $^{a}$ & - & - \\
\hline H ungary & & - \\
\hline Ireland & + & + \\
\hline Iceland $^{\mathrm{a}}$ & + & - \\
\hline Lithuania $^{a}$ & + & + \\
\hline N orway ${ }^{a}$ & + & + \\
\hline Sloveniab & - & - \\
\hline Sweden $^{a}$ & + & + (in part) \\
\hline $\begin{array}{l}\text { U nited } \\
\text { Kingdom }^{a}\end{array}$ & + & + \\
\hline $\begin{array}{l}\text { Countries } \\
\text { without natio- } \\
\text { nal action }\end{array}$ & $\begin{array}{l}\text { Official } \\
\text { documents }\end{array}$ & $\begin{array}{l}\text { A pproved } \\
\text { by } \\
\text { parliament }\end{array}$ \\
\hline A ndorra & - & - \\
\hline A zerbaijan & - & - \\
\hline Belarus & - & \\
\hline Belgium & + & - \\
\hline Bosnia \& & - & - \\
\hline H erzegovina & - & - \\
\hline C roatia & - & - \\
\hline G reece & - & - \\
\hline Israel ${ }^{C}$ & - & - \\
\hline Italy & - & - \\
\hline K yrgyzstan & - & - \\
\hline Latvia & - & - \\
\hline $\mathrm{N}$ etherlands & - & - \\
\hline Poland $^{c}$ & - & - \\
\hline $\begin{array}{l}\text { Republic of } \\
\text { M oldova }\end{array}$ & - & - \\
\hline Romania & & - \\
\hline $\begin{array}{l}\text { Russian } \\
\text { Federation }\end{array}$ & + & - \\
\hline Slovakia & - & - \\
\hline Spain & - & - \\
\hline Switzerland $^{\mathrm{C}}$ & - & - \\
\hline Turkey & + & - \\
\hline U kraine & - & - \\
\hline $\begin{array}{l}\text { Yugoslavia } \\
\text { (Serbia and } \\
\text { M onten egro) }\end{array}$ & - & - \\
\hline \multicolumn{3}{|c|}{$\begin{array}{l}\text { a Countries with a comprehensive national suicid } \\
\text { prevention programme. } \\
\text { b Countries with national strategies and a draft } \\
\text { national programme. } \\
\text { c Countries with plans for national action. }\end{array}$} \\
\hline
\end{tabular}

Table 2. T hemes of intervention in mental health care and public health in national suicide prevention activities

\begin{tabular}{|l|c|c|c|c|c|}
\hline \multirow{2}{*}{ C ountries } & \multicolumn{2}{|c|}{ Health care perspective } & \multicolumn{2}{c|}{ Public health perspective } \\
\cline { 2 - 6 } & Services $^{\mathrm{a}}$ & Education $^{\mathrm{a}}$ & M edia & A ccess & A wareness $^{\mathrm{a}}$ \\
\hline A ustria & + & + & + & + & + \\
\hline Bulgaria & + & + & + & - & + \\
\hline C zech & + & + & - & + & + \\
Republic & + & + & - & - & + \\
\hline Denmark & + & + & - & - & + \\
\hline Estonia & + & + & + & - & + \\
\hline Finland & + & + & + & + & + \\
\hline France & + & + & + & - & + \\
\hline G ermany & + & + & + & - & + \\
\hline G eorgia & + & + & + & - & + \\
\hline H ungary & + & + & - & - & + \\
\hline Iceland & + & + & + & + & + \\
\hline Ireland & + & + & + & - & + \\
\hline Lithuania & + & + & + & + & + \\
\hline N orway & + & + & + & - & + \\
\hline Slovenia & + & + & + & - & + \\
\hline Sweden & + & + & + & + & + \\
\hline United & + & & + & & + \\
\hline Kingdom & + & + & + & + \\
\hline
\end{tabular}

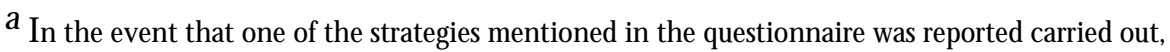
the answer was considered to be positive ( + ) for the country in question.

W hile only a few countries have public health interventions on suicide prevention that cover the entire population, most of the countries focus on children and adolescents, the elderly, families and special risk groups including suicide attempters, the depressed and the unemployed.

\section{d) Monitoring and evaluation}

It is not only important in suicide prevention to initiate and implement suicide prevention activities, but also to continuously monitor cases of suicide and attempted suicide in order to identify trends, risk groups and protective factors. Extensive research is carried out within the W $\mathrm{H} O$ European M ulticentre Study, which included 32 centres in 26 European countries at the time this report was prepared. $M$ ore centres are on the way to join the project. In addition, the work involves the evaluation of suicide prevention activities, both on the European and national levels, and in different regions of every European country. In all countries, suicides are monitored on the national level, and in most of them on the regional level as well. Evaluation of national suicide prevention initiatives has been carried out in less than one third of countries. In more than half of the countries a national institute is involved in coordinating suicide prevention activities.

\section{Countries without national suicide prevention activities}

Various suicide prevention activities are carried out under regional health care and public health initiatives, and many of these regional projects function as nuclei for further activities and their coordination.

Regional suicide prevention activities aim to lower the rates of completed and attempted suicide. A combination of strategies to improve health care services can be identified in most of these countries, including improved access to mental health services and crisis intervention, but also improvement of the awareness of health care providers concerning suicide prevention. In some countries, however, only single initiatives have been established, and a broader array of activities to improve health care services remains to be initiated and included in the regional projects.

The main target groups for the educational projects are general practitioners (in $75 \%$ of countries) and psychiatric personnel (in around half of the countries). the diagnosis of psychiatric illness and on adequate treatment, follow-up and rehabilitation of psychiatric patients and those who attempt suicide. The projects focus primarily on improving 
W hile all countries report some kind of public education in their regional activities, projects that control media reporting or access to means of suicide are rarely applied. Public education projects, intended to increase knowledge not only on prevention of suicidal behaviour but also on the treatment of mental illness in the community, are primarily carried out in schools. 0 ther settings are workplaces, housing areas, the military, prisons, the police offices, the church and the media. The number of different arenas in which regional educational projects are reported to be carried out varies considerably between countries.

W hile only few countries have public health interventions covering the whole population, most of the countries focus on children and adolescents, the elderly, families and special risk groups including suicide attempters, prisoners (U kraine), children of al coholics and victims of violence (Poland) and drug abusers, alcoholics, unskilled workers and participants in combat operations (Russian Federation).

In many of these countries, reported regional suicide prevention activities are comprehensive and form a basis for further initiatives in the countries. In Belgium, for example, owing to the federal nature of the country and regional responsibility for preventive health policy, a comprehensive programme exists in the Flemish region whereas isolated activities are carried out in the Walloon region.

There is a great variation in agencies implementing regional suicide prevention initiatives. In most of the countries ministerial agencies (Kyrgyzstan), national research centres ( $G$ reece, R ussian Federation) and national and regional public health institutes and agencies (I celand and Switzerland) on the one hand, and nongovernmental organizations such as helplines (A zerbaijan, Italy, R ussian Federation, U kraine) and psychiatric and medical associations (A zerbaijan, C roatia, Spain, Switzerland, U kraine) on the other, are involved in implementation. In some countries prevention or intervention centres and associations at regional level (Belgium, Kyrgyzstan, U kraine, Serbia and $M$ ontenegro) or local medical agencies (Kyrgyzstan, Russian Federation) are also involved. In A ndorra, Belgium and the $\mathrm{N}$ etherlands, mental health services and institutes are the main prevention institutions. Several programmesin Poland and $U$ kraine are carried out within the prison, military and police services.

In all countries suicides are monitored at national level, and in more than half of them at regional level as well. In Switzerland, Israel and Poland plans for national action have al ready been laid. In Belgium, G reece, Israel and the Russian Federation national institutes are available and could be involved in coordinating national activities.

\section{Obstacles experience and WHO support expressed}

Several obstacles for implementation of suicide preventive activities have been reported from the countries, like lack of governmental support, financial constraints, lack of co-ordination and special ised staff, as well as poorly devel oped mental health services. Therefore, the most frequently expressed requests from the countries concerning support from W H O are: raising government awareness; financial support; and technical support in: developing suicide prevention programmes, establishing recommen dations based on clinical and scientific evidence, national assessments, professional training, expert exchange and organization of meetings.

\section{Summary and outlook}

The results of these monitoring surveys give an interesting picture of the comprehensiveness of national initiatives and the complexity and richness of practical experience in the countries. They reflect a need to expand the $\mathrm{N}$ etwork further to include all W HO European M ember States where suicidal behaviour is a problem, either in society as a whole or in certain populations at risk. This picture of the situation of suicide prevention in W HO European M ember States will be continuousl y followed up, monitored and updated. This unique summary of suicide preventive activities in the W HO European Region is intended to serve European policy makers in the area of $\mathrm{M}$ ental $\mathrm{H}$ ealth as an important document. Furthermore, the continuously updated documentation of national efforts in suicide prevention in relation to the situation in other countries in the W HO/EU RO network on suicide prevention, will help member states to raise governmental awareness and support.

\section{Recommended reading}

Bille-Brahe, U. W H O/EU RO multicentre study on parasuicide: facts and figures, 2 nd ed. Copenhagen, W HO Regional O ffice for Europe, 1999 (document EUR/IC P/H PSA 0106 03).

$\mathrm{H}$ ealth21. T he health for all policy framework for the W H $O$ European R egion. C openhagen, W H O Regional Office for Europe, 1999 (European $\mathrm{H}$ ealth for A II Series, N 0. 6).

Kerkhof, A .J.F.M . et al. A ttempted suicide in Europe. Leiden, DSW O Press, 1994.

Targets for health for all. Targets in support of the European regional strategy for health for all. Copenhagen, W HO Regional O ffice for Europe, 1985 (European $\mathrm{H}$ ealth for A II Series, N 0. 1).

The world health report 2001: mental health: new understanding, new hope. G eneva, W orld H ealth O rganization, 2001.

Wasserman, D. et al. Suicide prevention in Europe: the W H 0 monitoring surveys on national suicide prvention programmes and strategies. Stockholm: N A SP, 2003. www.ki.se/suicide//rapporter/ Suicide_Prevention_in_Europe.pdf

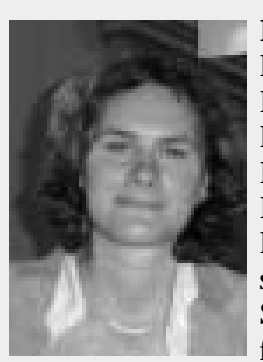

Ellenor Mittendorfer R utz, M Sc is PhD student at the $N$ ational Institute of Psychosocial Medicine/ $\mathrm{N}$ ational C entre on Suicide Research and Prevention of M ental III-H ealth/Karolinska Institute in Stockholm, Sweden. $\mathrm{H}$ er research focuses on epidemiological studies analysing pre-and perinatal, psychosocial as well as psychiatric risk factors for suicide and suicide attempt in adolescents and young adults.

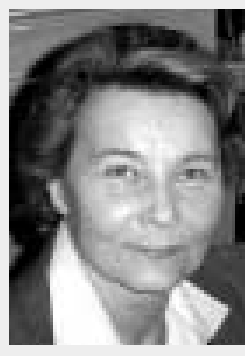

D anuta W asserman, M D, PhD is Professor of Psychiatry and Suicidology at the $\mathrm{N}$ ational Institute of Psychosocial M edicine/ Karolinska Institute in Stockholm, Sweden, and also $\mathrm{H}$ ead of the $\mathrm{N}$ ational Swedish and Stockholm County Centre and W HO Collaboration Centre on Suicide Research and Prevention of M ental III-H ealth. Professor W asserman's research focuses on an interdisciplinary approach that elucidates psychodynamic, psychiatric and genetic aspects of suicidal behaviour. 
Table 1. Level of national action on suicide prevention

\begin{tabular}{|c|c|c|}
\hline $\begin{array}{l}\text { C ountries } \\
\text { with national } \\
\text { prevention } \\
\text { initiatives }\end{array}$ & $\begin{array}{l}0 \text { fficial } \\
\text { documents }\end{array}$ & $\begin{array}{l}\text { A pproved } \\
\text { by } \\
\text { parliament }\end{array}$ \\
\hline A ustria ${ }^{a}$ & + & - \\
\hline Bulgaria $^{a}$ & + & - \\
\hline $\begin{array}{l}\text { C zech } \\
\text { Republic }^{a}\end{array}$ & + & - \\
\hline Denmark $^{a}$ & + & + \\
\hline Estonia $^{b}$ & + & - \\
\hline Finland $^{a}$ & + & - \\
\hline France $^{a}$ & + & - \\
\hline G eorgia & + & + \\
\hline G ermany $^{a}$ & - & - \\
\hline H ungary & & - \\
\hline Ireland & + & + \\
\hline Iceland $^{\mathrm{a}}$ & + & - \\
\hline Lithuania $^{a}$ & + & + \\
\hline N orway ${ }^{a}$ & + & + \\
\hline Sloveniab & - & - \\
\hline Sweden $^{a}$ & + & + (in part) \\
\hline $\begin{array}{l}\text { U nited } \\
\text { Kingdom }^{a}\end{array}$ & + & + \\
\hline $\begin{array}{l}\text { Countries } \\
\text { without natio- } \\
\text { nal action }\end{array}$ & $\begin{array}{l}\text { Official } \\
\text { documents }\end{array}$ & $\begin{array}{l}\text { A pproved } \\
\text { by } \\
\text { parliament }\end{array}$ \\
\hline A ndorra & - & - \\
\hline A zerbaijan & - & - \\
\hline Belarus & - & \\
\hline Belgium & + & - \\
\hline Bosnia \& & - & - \\
\hline H erzegovina & - & - \\
\hline C roatia & - & - \\
\hline G reece & - & - \\
\hline Israel ${ }^{C}$ & - & - \\
\hline Italy & - & - \\
\hline K yrgyzstan & - & - \\
\hline Latvia & - & - \\
\hline $\mathrm{N}$ etherlands & - & - \\
\hline Poland $^{c}$ & - & - \\
\hline $\begin{array}{l}\text { Republic of } \\
\text { M oldova }\end{array}$ & - & - \\
\hline Romania & & - \\
\hline $\begin{array}{l}\text { Russian } \\
\text { Federation }\end{array}$ & + & - \\
\hline Slovakia & - & - \\
\hline Spain & - & - \\
\hline Switzerland $^{\mathrm{C}}$ & - & - \\
\hline Turkey & + & - \\
\hline U kraine & - & - \\
\hline $\begin{array}{l}\text { Yugoslavia } \\
\text { (Serbia and } \\
\text { M onten egro) }\end{array}$ & - & - \\
\hline \multicolumn{3}{|c|}{$\begin{array}{l}\text { a Countries with a comprehensive national suicid } \\
\text { prevention programme. } \\
\text { b Countries with national strategies and a draft } \\
\text { national programme. } \\
\text { c Countries with plans for national action. }\end{array}$} \\
\hline
\end{tabular}

Table 2. T hemes of intervention in mental health care and public health in national suicide prevention activities

\begin{tabular}{|l|c|c|c|c|c|}
\hline \multirow{2}{*}{ C ountries } & \multicolumn{2}{|c|}{ Health care perspective } & \multicolumn{2}{c|}{ Public health perspective } \\
\cline { 2 - 6 } & Services $^{\mathrm{a}}$ & Education $^{\mathrm{a}}$ & M edia & A ccess & A wareness $^{\mathrm{a}}$ \\
\hline A ustria & + & + & + & + & + \\
\hline Bulgaria & + & + & + & - & + \\
\hline C zech & + & + & - & + & + \\
Republic & + & + & - & - & + \\
\hline Denmark & + & + & - & - & + \\
\hline Estonia & + & + & + & - & + \\
\hline Finland & + & + & + & + & + \\
\hline France & + & + & + & - & + \\
\hline G ermany & + & + & + & - & + \\
\hline G eorgia & + & + & + & - & + \\
\hline H ungary & + & + & - & - & + \\
\hline Iceland & + & + & + & + & + \\
\hline Ireland & + & + & + & - & + \\
\hline Lithuania & + & + & + & + & + \\
\hline N orway & + & + & + & - & + \\
\hline Slovenia & + & + & + & - & + \\
\hline Sweden & + & + & + & + & + \\
\hline United & + & & + & & + \\
\hline Kingdom & + & + & + & + \\
\hline
\end{tabular}

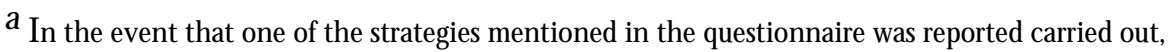
the answer was considered to be positive ( + ) for the country in question.

W hile only a few countries have public health interventions on suicide prevention that cover the entire population, most of the countries focus on children and adolescents, the elderly, families and special risk groups including suicide attempters, the depressed and the unemployed.

\section{d) Monitoring and evaluation}

It is not only important in suicide prevention to initiate and implement suicide prevention activities, but also to continuously monitor cases of suicide and attempted suicide in order to identify trends, risk groups and protective factors. Extensive research is carried out within the W $\mathrm{H} O$ European M ulticentre Study, which included 32 centres in 26 European countries at the time this report was prepared. $M$ ore centres are on the way to join the project. In addition, the work involves the evaluation of suicide prevention activities, both on the European and national levels, and in different regions of every European country. In all countries, suicides are monitored on the national level, and in most of them on the regional level as well. Evaluation of national suicide prevention initiatives has been carried out in less than one third of countries. In more than half of the countries a national institute is involved in coordinating suicide prevention activities.

\section{Countries without national suicide prevention activities}

Various suicide prevention activities are carried out under regional health care and public health initiatives, and many of these regional projects function as nuclei for further activities and their coordination.

Regional suicide prevention activities aim to lower the rates of completed and attempted suicide. A combination of strategies to improve health care services can be identified in most of these countries, including improved access to mental health services and crisis intervention, but also improvement of the awareness of health care providers concerning suicide prevention. In some countries, however, only single initiatives have been established, and a broader array of activities to improve health care services remains to be initiated and included in the regional projects.

The main target groups for the educational projects are general practitioners (in $75 \%$ of countries) and psychiatric personnel (in around half of the countries). the diagnosis of psychiatric illness and on adequate treatment, follow-up and rehabilitation of psychiatric patients and those who attempt suicide. The projects focus primarily on improving 
W hile all countries report some kind of public education in their regional activities, projects that control media reporting or access to means of suicide are rarely applied. Public education projects, intended to increase knowledge not only on prevention of suicidal behaviour but also on the treatment of mental illness in the community, are primarily carried out in schools. 0 ther settings are workplaces, housing areas, the military, prisons, the police offices, the church and the media. The number of different arenas in which regional educational projects are reported to be carried out varies considerably between countries.

W hile only few countries have public health interventions covering the whole population, most of the countries focus on children and adolescents, the elderly, families and special risk groups including suicide attempters, prisoners (U kraine), children of al coholics and victims of violence (Poland) and drug abusers, alcoholics, unskilled workers and participants in combat operations (Russian Federation).

In many of these countries, reported regional suicide prevention activities are comprehensive and form a basis for further initiatives in the countries. In Belgium, for example, owing to the federal nature of the country and regional responsibility for preventive health policy, a comprehensive programme exists in the Flemish region whereas isolated activities are carried out in the Walloon region.

There is a great variation in agencies implementing regional suicide prevention initiatives. In most of the countries ministerial agencies (Kyrgyzstan), national research centres ( $G$ reece, R ussian Federation) and national and regional public health institutes and agencies (I celand and Switzerland) on the one hand, and nongovernmental organizations such as helplines (A zerbaijan, Italy, R ussian Federation, U kraine) and psychiatric and medical associations (A zerbaijan, C roatia, Spain, Switzerland, U kraine) on the other, are involved in implementation. In some countries prevention or intervention centres and associations at regional level (Belgium, Kyrgyzstan, U kraine, Serbia and $M$ ontenegro) or local medical agencies (Kyrgyzstan, Russian Federation) are also involved. In A ndorra, Belgium and the $\mathrm{N}$ etherlands, mental health services and institutes are the main prevention institutions. Several programmesin Poland and $U$ kraine are carried out within the prison, military and police services.

In all countries suicides are monitored at national level, and in more than half of them at regional level as well. In Switzerland, Israel and Poland plans for national action have al ready been laid. In Belgium, G reece, Israel and the Russian Federation national institutes are available and could be involved in coordinating national activities.

\section{Obstacles experience and WHO support expressed}

Several obstacles for implementation of suicide preventive activities have been reported from the countries, like lack of governmental support, financial constraints, lack of co-ordination and special ised staff, as well as poorly devel oped mental health services. Therefore, the most frequently expressed requests from the countries concerning support from W H O are: raising government awareness; financial support; and technical support in: developing suicide prevention programmes, establishing recommen dations based on clinical and scientific evidence, national assessments, professional training, expert exchange and organization of meetings.

\section{Summary and outlook}

The results of these monitoring surveys give an interesting picture of the comprehensiveness of national initiatives and the complexity and richness of practical experience in the countries. They reflect a need to expand the $\mathrm{N}$ etwork further to include all W HO European M ember States where suicidal behaviour is a problem, either in society as a whole or in certain populations at risk. This picture of the situation of suicide prevention in W HO European M ember States will be continuousl y followed up, monitored and updated. This unique summary of suicide preventive activities in the W HO European Region is intended to serve European policy makers in the area of $\mathrm{M}$ ental $\mathrm{H}$ ealth as an important document. Furthermore, the continuously updated documentation of national efforts in suicide prevention in relation to the situation in other countries in the W HO/EU RO network on suicide prevention, will help member states to raise governmental awareness and support.

\section{Recommended reading}

Bille-Brahe, U. W H O/EU RO multicentre study on parasuicide: facts and figures, 2 nd ed. Copenhagen, W HO Regional O ffice for Europe, 1999 (document EUR/IC P/H PSA 0106 03).

$\mathrm{H}$ ealth21. T he health for all policy framework for the W H $O$ European R egion. C openhagen, W H O Regional Office for Europe, 1999 (European $\mathrm{H}$ ealth for A II Series, N 0. 6).

Kerkhof, A .J.F.M . et al. A ttempted suicide in Europe. Leiden, DSW O Press, 1994.

Targets for health for all. Targets in support of the European regional strategy for health for all. Copenhagen, W HO Regional O ffice for Europe, 1985 (European $\mathrm{H}$ ealth for A II Series, N 0. 1).

The world health report 2001: mental health: new understanding, new hope. G eneva, W orld H ealth O rganization, 2001.

Wasserman, D. et al. Suicide prevention in Europe: the W H 0 monitoring surveys on national suicide prvention programmes and strategies. Stockholm: N A SP, 2003. www.ki.se/suicide//rapporter/ Suicide_Prevention_in_Europe.pdf

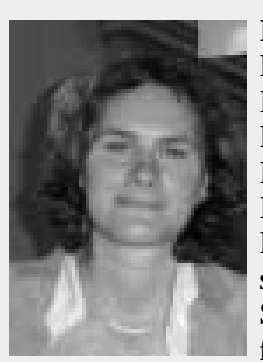

Ellenor Mittendorfer R utz, M Sc is PhD student at the $N$ ational Institute of Psychosocial Medicine/ $\mathrm{N}$ ational C entre on Suicide Research and Prevention of M ental III-H ealth/Karolinska Institute in Stockholm, Sweden. $\mathrm{H}$ er research focuses on epidemiological studies analysing pre-and perinatal, psychosocial as well as psychiatric risk factors for suicide and suicide attempt in adolescents and young adults.

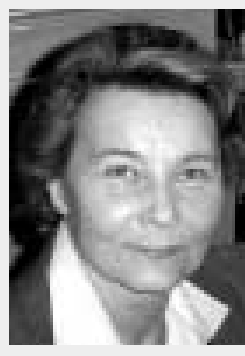

D anuta W asserman, M D, PhD is Professor of Psychiatry and Suicidology at the $\mathrm{N}$ ational Institute of Psychosocial M edicine/ Karolinska Institute in Stockholm, Sweden, and also $\mathrm{H}$ ead of the $\mathrm{N}$ ational Swedish and Stockholm County Centre and W HO Collaboration Centre on Suicide Research and Prevention of M ental III-H ealth. Professor W asserman's research focuses on an interdisciplinary approach that elucidates psychodynamic, psychiatric and genetic aspects of suicidal behaviour. 